\title{
A Study of Women Entrepreneurship and Their Problems in the Development in Western Maharashtra
}

\author{
Jadhawrao Madhavi Sugaraj $^{* 1}$, Dr. Salve P.S. ${ }^{2}$ \\ ${ }^{I}$ Research Scholar, Shri jagdish prasad jhabarmal tibrewala university, vidyanagari, jhunjhunu, rajasthan - \\ 333001. \\ ${ }^{2}$ Research Scholar, Shri jagdish prasad jhabarmal tibrewala university, vidyanagari, jhunjhunu, rajasthan - \\ 333001 .
}

\begin{abstract}
This study is based on the secondary source of data which are collected from Fourth All India Census on MSME (Micro, Small and Medium Enterprises) published by Government of India. The limitation of the study is availability of data. The latest data available regarding women entrepreneurs are for the year 200607, published by Government of India through Fourth All India Census on MSME. Government of India in Ministry of MSME has conducted three Censuses of registered Small Scale Industries (SSI) prior to the enactment of MSME Development Act, 2006. The last Census was conducted in 2002-03 with reference year 2001-02, the Government of India published data only for registered SSI (Small Scale Industries) sector in the $1^{s t}$ and 2 nd censuses. These censuses did not provide data on women enterprises in the same manner as the Fourth Census provided. Because of this our study only refers to a particular point of time (2006-07) rather than making any "over the period analysis". Considering the importance of database for policy formulation, an All India 4th Census was introduced in 2008.
\end{abstract}

Keywords: Women Entrepreneurship, Government of India, Western Maharashtra, Demographic Profile.

\section{Introduction}

The research makes an attempt to analyse women's participation in entrepreneurial activities so as to highlight the contribution of women entrepreneurs towards economic development. In the process it further attempts to examine the facilitating factors as well as impediments that this class face in running their units. Policies and programmes of the government also exist to promote and strengthen the development of women entrepreneurship in India ${ }^{1}$. The focus of the paper is on women participation in small business ventures in India, since most of the women entrepreneurs are engaged in this sector. The Government of India has defined women entrepreneurs based on women participation in equity and employment of a business enterprise. Accordingly, a women enterprise is defined as "an enterprise owned and controlled by a women having a minimum financial interest of $51 \%$ of the capital and giving at least $51 \%$ of the employment generated in the enterprise to women". Women enterprises can be classified as: (i) owned by women, (ii) managed by women and (iii) employing women ${ }^{2}$.

Most of the studies (books and articles by foreign as well as Indian research scholars) on Entrepreneurship are micro-level research based on limited number of samples. These studies have been carried out at different points of time during the last five decades and deal with diverse situations. There is considerable literature on women's studies in the developed countries. However the socio-economic conditions prevailing, the infrastructural facilities available and the level of development of industries, trade and commerce in the West are very different from the conditions available in India. Hence, their comparisons with the Indian scenario would not reflect the reality in toto. Therefore, drawing conclusions from them also would neither be valid nor totally realistic ${ }^{3}$.

\section{Methodology}

The target industry for the study is small scale sector i.e. the firms having investment in plant and machinery at an original cost not exceeding Rs. 1 crore. The population of the study is confined to the women entrepreneurs in Pune district, who are registered under District Industries Centre (D.I.C.) Pune region. The firms that are in operation for at least last 5 years are included in the study. The population of the study is 250 women run small scale enterprises. For the purpose of this study the required database of women entrepreneurs is been collected from D.I.C. Pune regional office. The cluster sampling method is used to derive the sample. Out of the population of 250 women run enterprises 25 per cent i.e. 63 enterprises are taken as sample. The total population of 250 enterprises is divided into various sub areas (sub areas being sub urban areas of Pune city) ${ }^{\mathbf{4 , 5}}$. For selecting the sample from each sub urban area convenient sampling method is used. 
Table 1: Area wise Population \& Sample

\begin{tabular}{|c|c|c|}
\hline $\begin{array}{c}\text { Sub Urban Area of Pune } \\
\text { City }\end{array}$ & Population in the Area & $\begin{array}{c}\text { Samples selected from the } \\
\text { area }\end{array}$ \\
\hline Narhe -Ambegaon & 16 & 4 \\
\hline Bhosari & 28 & 7 \\
\hline Pimpari - Chinchwad & 20 & 10 \\
\hline Chakan & 40 & 2 \\
\hline Dhayari & 10 & 5 \\
\hline Kothrud & 20 & 5 \\
\hline Karve Nagar & 20 & 8 \\
\hline Bavadhan & 32 & 11 \\
\hline Ranjangaon & 42 & 6 \\
\hline Hinjewadi & 22 & 63 \\
\hline Total & 250 & \\
\hline
\end{tabular}

The area wise distribution of total population and the proportionately selected samples is shown in the following table -

- The primary data is collected through questionnaire and in depth interviews.

- The secondary data is collected through the review of existing literature related with the topic.

- The review is made using books, magazines, newspapers, journals and research thesis. The secondary data is also collected from D.I.C. (District Industries Centre) and M.C.E.D. (Maharashtra Centre for Entrepreneurship Development) Pune region offices and websites.

- The tools used for data collection are questionnaire, in depth interviews and informal interaction with the respondents. The in depth interviews of 10 respondents were conducted in order to gain better understanding of their operations. Questionnaire was prepared for the respondents including open and closed ended questions.

This study is based on secondary sources of data provided by government reports, internet sources, review of some selected articles, periodicals etc. To find out the factors motivating the women entrepreneurs to start their own enterprise and major constraints faced by them t-test has been administered. Percentage analysis has also been used to find out the demographic profiles of the respondents ${ }^{6}$.

\section{Profile of the women entrepreneurs}

\section{Data Analysis \& Discussion}

The demographic profile of the respondents is given in Table 1 . Out of the 63 respondents taken for the study 40 per cent belong to the age - group of 33-40 years. Regarding the marital status 83 per cent are married, 79 per cent have children and 71 per cent have children above 10 years of age. 38 per cent have completed their studies up to graduation and 59 per cent have the work experience. Regarding the family type 73 per cent have nuclear families and 87 per cent get support of their family members, 40 per cent get the support in the form of emotional support. 76 per cent women entrepreneurs are first generation entrepreneurs, 51 per cent have their business premises as a part of their house. 21 per cent are engaged in fashion designing and tailoring and 14 per cent run beauty parlor. 40 per cent women spend 4-8 hours in their business. 60 per cent have used their own funds to start the business while 40 percent have borrowed from various sources of which 19 per cent have borrowed from their relatives. For 59 per cent of the respondents their business is not the only source of income $^{7,8}$.

Table 2: Demographic Profile

\begin{tabular}{|c|c|c|c|}
\hline Particulars & Classification & Number & Percentage \\
\hline Age Group & $\begin{array}{c}\text { Below } 25 \text { years } \\
25-32 \text { years } \\
33-40 \text { years } \\
40-55 \text { years } \\
\text { Above } 55 \text { years }\end{array}$ & $\begin{array}{c}5 \\
14 \\
25 \\
16 \\
3\end{array}$ & $\begin{array}{c}8 \\
22 \\
40 \\
25 \\
5\end{array}$ \\
\hline Marital Status & $\begin{array}{l}\text { Married } \\
\text { Unmarried } \\
\text { Widowed } \\
\text { Divorced }\end{array}$ & $\begin{array}{c}52 \\
11 \\
0 \\
0\end{array}$ & $\begin{array}{c}83 \\
17 \\
0 \\
0\end{array}$ \\
\hline Children & $\begin{array}{l}\text { Yes } \\
\text { No }\end{array}$ & $\begin{array}{l}50 \\
13 \\
\end{array}$ & $\begin{array}{l}79 \\
21 \\
\end{array}$ \\
\hline $\begin{array}{l}\text { Age Group of } \\
\text { Children }\end{array}$ & $\begin{array}{c}\text { Below } 5 \text { years } \\
5-10 \text { years } \\
\text { Above } 10 \text { years }\end{array}$ & $\begin{array}{c}6 \\
12 \\
45 \\
\end{array}$ & $\begin{array}{l}10 \\
19 \\
71 \\
\end{array}$ \\
\hline $\begin{array}{l}\text { Highest Educational } \\
\text { Qualification }\end{array}$ & $\begin{array}{c}\text { Primary school } \\
\text { Secondary School }\end{array}$ & $\begin{array}{c}7 \\
12\end{array}$ & $\begin{array}{l}11 \\
19\end{array}$ \\
\hline
\end{tabular}




\begin{tabular}{|c|c|c|c|}
\hline & $\begin{array}{l}\text { High school } \\
\text { Graduate } \\
\text { Post Graduate } \\
\text { Illiterate } \\
\end{array}$ & $\begin{array}{c}14 \\
24 \\
4 \\
2 \\
\end{array}$ & $\begin{array}{c}22 \\
38 \\
7 \\
3 \\
\end{array}$ \\
\hline Work Experience & $\begin{array}{l}\text { Yes } \\
\text { No }\end{array}$ & $\begin{array}{l}37 \\
26\end{array}$ & $\begin{array}{l}59 \\
41\end{array}$ \\
\hline Family Type & $\begin{array}{l}\text { Nuclear family } \\
\text { Joint family }\end{array}$ & $\begin{array}{l}46 \\
17\end{array}$ & $\begin{array}{l}73 \\
27 \\
\end{array}$ \\
\hline Family Members Support & No & 8 & 13 \\
\hline Form of Support & $\begin{array}{c}\text { Manual help } \\
\text { Emotional support } \\
\text { Financial help } \\
\text { Advice }\end{array}$ & $\begin{array}{l}28 \\
40 \\
29 \\
13 \\
\end{array}$ & $\begin{array}{l}26 \\
36 \\
26 \\
12 \\
\end{array}$ \\
\hline Category of Business & $\begin{array}{c}\text { First generation Entrepreneur } \\
\text { Parents as entrepreneurs } \\
\text { In-laws as entrepreneurs }\end{array}$ & $\begin{array}{c}48 \\
6 \\
9 \\
\end{array}$ & $\begin{array}{l}76 \\
10 \\
14 \\
\end{array}$ \\
\hline $\begin{array}{l}\text { Nature of factory } \\
\text { building }\end{array}$ & $\begin{array}{c}\text { Part of house } \\
\text { Separate building }\end{array}$ & $\begin{array}{l}32 \\
31\end{array}$ & $\begin{array}{l}52 \\
59 \\
\end{array}$ \\
\hline Type of enterprise & $\begin{array}{c}\text { Fashion Designing \& Tailoring } \\
\text { Interior Designing } \\
\text { Confectionary \& Bakery } \\
\text { Beauty Parlor } \\
\text { Grocery Shop } \\
\text { Internet / Mobile application services } \\
\text { Financial Services } \\
\text { Agriculture } \\
\text { Medical \& General Stores } \\
\text { Other activities }\end{array}$ & $\begin{array}{c}13 \\
1 \\
7 \\
9 \\
7 \\
2 \\
1 \\
2 \\
4 \\
17 \\
\end{array}$ & $\begin{array}{c}21 \\
2 \\
11 \\
14 \\
11 \\
3 \\
2 \\
3 \\
6 \\
27\end{array}$ \\
\hline $\begin{array}{l}\text { Time spent in } \\
\text { business }\end{array}$ & $\begin{array}{c}\text { Up to } 4 \text { hours } \\
4-8 \text { hours } \\
8-12 \text { hours } \\
\text { Above } 12 \text { hours } \\
\end{array}$ & $\begin{array}{c}9 \\
25 \\
19 \\
10 \\
\end{array}$ & $\begin{array}{l}14 \\
40 \\
30 \\
16 \\
\end{array}$ \\
\hline Sources of Funds & $\begin{array}{c}\text { Own funds only } \\
\text { Own funds \& borrowed } \\
\text { funds }\end{array}$ & $\begin{array}{l}38 \\
25\end{array}$ & $\begin{array}{l}60 \\
40\end{array}$ \\
\hline $\begin{array}{l}\text { Sources of } \\
\text { Borrowings }\end{array}$ & $\begin{array}{c}\text { Relatives } \\
\text { Friends } \\
\text { Commercial banks } \\
\text { Co-operative banks } \\
\text { Financial institutions } \\
\text { NA }\end{array}$ & $\begin{array}{c}12 \\
4 \\
9 \\
4 \\
5\end{array}$ & $\begin{array}{c}19 \\
7 \\
14 \\
6 \\
8\end{array}$ \\
\hline $\begin{array}{l}\text { Business as Main } \\
\text { source of income }\end{array}$ & $\begin{array}{l}\text { Yes } \\
\text { No }\end{array}$ & $\begin{array}{l}26 \\
37 \\
\end{array}$ & $\begin{array}{l}41 \\
59 \\
\end{array}$ \\
\hline
\end{tabular}

\section{Women's Entrepreneurship Development (WED)}

The ILO's Women's Entrepreneurship Development programme (ILO-WED) is part of the SmallEnterprise Development Programme (SEED). ILO-WED works on enhancing economic opportunities for women by carrying out affirmative actions in support of women starting, formalizing and growing their enterprises, and by mainstreaming gender equality issues into the ILO's work in enterprise development. This approach to WED is highlighted in the ILO WED Strategy that was adopted by the Governing Body in March, $2008^{9}$.

The ILO-WED approach is threefold, working with governments, employers' organizations, trade unions, and local community-based organizations to: create an enabling environment for WED that generates quality jobs; build institutional capacity in WED; and development of tools and support services for women entrepreneurs. It does so both through targeted approaches and gender mainstreaming, with a clear objective to contribute towards gender equality and women's economic empowerment.

\section{Results And Discussion}

\section{Factors motivating women to become entrepreneurs}

In order to find out the factors motivating the women to become entrepreneurs 23 attributes that can influence their decision to become entrepreneur were identified ${ }^{\mathbf{1 0}}$. The respondents were then requested to express their level of opinion on the influence of those factors on a 5 point Likert-scale. The output of t-test performed to identify the significant factors motivating women entrepreneurs to start their own enterprise is shown in Table 3. 
Table 3: Motivating Factors

\begin{tabular}{|c|c|c|c|c|}
\hline \multirow[t]{2}{*}{ Motivating Factors } & \multicolumn{4}{|c|}{ Test Value $=3$} \\
\hline & $\mathbf{T}$ & df & Sig. (2-tailed) & Mean Difference \\
\hline Dissatisfaction with current job & 0.653 & 62 & 0.214 & 0.214 \\
\hline Use of idle funds & 3.503 & 34 & 0.256 & 0.476 \\
\hline Availability of Infrastructural facilities & 1.278 & 45 & 0.125 & 0.378 \\
\hline Market potential & 4.245 & 65 & 0.000 & 0.459 \\
\hline Support from family & 9.150 & 53 & 0.000 & 0.128 \\
\hline $\begin{array}{l}\text { Gaining respect from others for my } \\
\text { skills and talent }\end{array}$ & 4.212 & 57 & 0.233 & 0.774 \\
\hline Seeking challenging business venture & 3.682 & 58 & 0.024 & 0.436 \\
\hline To make more money & 4.761 & 34 & 0.022 & 0.327 \\
\hline Being entrepreneur was a lifelong goal & 5.315 & 52 & 0.000 & 0.186 \\
\hline Freedom from supervision & 2.046 & 54 & 0.246 & 0.450 \\
\hline To spend spare time & 2.713 & 54 & 0.421 & 0.247 \\
\hline Family business passed on to me & 0.851 & 58 & 0.245 & 0.774 \\
\hline To support family financially & 5.520 & 60 & 0.324 & 0.701 \\
\hline $\begin{array}{l}\text { Responsibility to run business due to } \\
\text { death of member }\end{array}$ & -2.863 & 61 & 0.000 & 0.724 \\
\hline To advance myself & 4.293 & 49 & 0.124 & 0375 \\
\hline
\end{tabular}

The above table shows the factors which are significant for motivating women entrepreneurs. The decision rule used to find out the significant factor is $t$ value $>o$ and sigma $<.05$. accordingly 17 factors i.e. economic independence, use of idle funds, market potential, social status, support from family, gaining respect from others for skill and talent, seeking challenging business venture, making more money, gaining control on life, getting better life than before, to prove myself, self esteem, being entrepreneur was lifelong goal, freedom form supervision, To support family financially, to spend spare time and To advance myself these factors proved to be significant. Hence, the remaining 6 factors namely dissatisfaction with current job, unemployment, Availability of Infrastructural facilities, no other income source available, Responsibility to run business due to death of family member, family business passed on to me proved to be insignificant ${ }^{11}$.

\section{Constraints/challenges faced in a journey as entrepreneur}

In order to find out what constraint / challenges women entrepreneurs have faced in their journey as entrepreneur, total constraint were divided into 4 categories as constraint on personal level, social level, environmental level and general constraint they are still facing.

\section{Personal Level Constraints}

In the category of personal level constraints 12 attributes were identified. The t- test performed to identify the significant personal level constraints faced by women entrepreneurs gives the output shown in Table 4.

Table 4: Personal Constraints

\begin{tabular}{|c|c|c|c|c|}
\hline \multirow[t]{2}{*}{ Personal Constraints } & \multicolumn{4}{|c|}{ Test Value $=3$} \\
\hline & $\mathbf{T}$ & df & Sig. (2-tailed) & Mean Difference \\
\hline Poor Self Image & 1.348 & 54 & 0.000 & 1.060 \\
\hline $\begin{array}{l}\text { Lack of motivation and } \\
\text { confidence }\end{array}$ & 9.653 & 60 & 0.014 & -0.214 \\
\hline Role conflict & -1.028 & 40 & 0.500 & 1.745 \\
\hline Lack of leadership qualities & 21.503 & 44 & 0.056 & 0.076 \\
\hline $\begin{array}{l}\text { usceptibility about own } \\
\text { decision making abilities }\end{array}$ & 14.278 & 40 & 0.325 & -0.678 \\
\hline Orthodox family background & 10.245 & 61 & 0.030 & 0.359 \\
\hline Lack of finance & 23.733 & 56 & 0.040 & -1.589 \\
\hline Lack of security & 12.643 & 50 & 0.054 & 1.854 \\
\hline $\begin{array}{l}\text { Physical constraints like } \\
\text { pregnancy }\end{array}$ & 5.150 & 59 & 1.000 & -0.128 \\
\hline $\begin{array}{l}\text { Lack of support from } \\
\text { husband and family }\end{array}$ & 3.012 & 50 & 0.633 & 1.074 \\
\hline Fear of failure and criticism & 20.002 & 38 & 0.624 & 0.836 \\
\hline $\begin{array}{l}\text { Maintaining work life } \\
\text { balance }\end{array}$ & 3.061 & 44 & 0.322 & 0.927 \\
\hline
\end{tabular}


The above table shows the factors which are personal level constraints for women entrepreneurs. The decision rule used to find out the significant factor is $\mathrm{t}$ value $>\mathrm{o}$ and sigma $<.05$ accordingly 6 factors i.e. lack of motivation and confidence, role conflicts, lack of leadership qualities, orthodox family background, lack of finance, maintaining work life balance proved to be significant factors. Hence, the remaining 6 factors namely poor self image, susceptibility about own decision making, lack of security, physical constraints like pregnancy, lack of support from husband and family, fear of failure and criticism were proved to be insignificant.

\section{Summary And Conclusion}

There has been a steady increase in the participation of women in small business indicating immense potential for entrepreneurial development among them. From the point of view of performance, it was observed that the women enterprises in India have made significant contribution towards generation of employment, gross output, asset creation and exports. Women form the family, which participate to develop society and Nation. Entrepreneurial movement among women started late and is still in its infancy. Changes in the global and domestic environment have contributed towards the growth of women entrepreneurship in India. As observed the success of women entrepreneurs differs from State to State in India. It was also observed that women enterprises are concentrated in the micro segment of the MSME sector. To enlarge their participation in small and medium segments a stronger coordinated role of Indian Government, financial institutions, voluntary agencies and educational institutions with an integrated approach is necessary. Young female entrepreneurs should share their success stories in the world of e-commerce to speed up entrepreneurial movement in India. Women entrepreneurs will be better understood and encouraged by studying and focussing (i) their social and cultural background including family system (ii) religion and caste and (iii) location where they are staying, e.g., whether it is urban area or rural area or district or block.

The above review of Indian research reveals that studies conducted in the past have covered various aspects such as motivation, available support system and problems faced by women entrepreneurs. Zimare (2006) has also carried out an earlier research under the title: Socio Economic Study of Women Entrepreneurs in Pune District.He had includedJain women entrepreneurs as a part of this study but the sample was small, i.e.15 only. Also Gangure Saroj Purushottam has done a research titled: "A comparative study of women entrepreneurs from business communities like Parsi, Sindhi, Bohari Marwari, Guajarati and non-business community like Maharashtra working in Pune and Pimpri Chinchwad Municipal Corporation Areas". Here too Jain women are studied but only from a comparative perspective; also the samples are limited to Pune and Pimpri-Chinchwad areas of the city. The project under study has a larger number of samples and will be applicable to the entire Pune district.

\section{References}

[1]. Bajaj, Shammi "women entrepreneurs: a new face of India", IJRIM, November 2012, Volume 2, Issue 11, $123-127$.

[2]. Batra, G.S: "Female Entrepreneurship", European Women Management Development Forum, Brussels, 1992

[3]. Das, Malika, Associate Professor, Deptt. of Business Administration and Tourism and Hospitality Management, Mount Saint Vincent University, Halifax, N.S. "Women Entrepreneurs from India: Problems, Motivations and Success Factors", Journal of Small Business \& Entrepreneurship, Winter 2000-2001, Vol. 15, No.4.

[4]. Desai Vasant, "Dynamics of Entrepreneurial Development and Management", 1992 Himalaya Publishing House.

[5]. Goplan, S: "Employment of Women: The Indian Situation", Second International Conference of Women Entrepreneurs, NAYE, New Delhi, 1981.

[6]. Goyal, Meenu and Jai Parkash "Women Entrepreneurship in India-Problems and Prospects", International Journal of Multidisciplinary Research, September 2011, Vol.1 Issue 5.

[7]. Blossom, O'Meally-Nelson, "Small Business Opportunities for Women in Jamaica : A Comment”,SEDME, Vol. XVIII, National Institute of Micro, Small and Medium Enterprises, March 1991.

[8]. Carter, Sara and Cannon, Tom, Women as Entrepreneurs: A Study of Female Business Owner, Their Motivations, Experiences and Strategies for Success, London and New York Academic Press, 1992.

[9]. Choudhury, P. K. Shashi, Baijal and Asokan, M. (1997), "Bank and Women Enterprise Development: A Comparison of Approaches in India and UK", SEDME, XXIV, National Institute of Micro, Small and Medium Enterprises, June 1997.

[10]. Nadkarni, Sulochana, "Social and Economic Study of Women Entrepreneurs with Reference to Pune", Ph.D. Thesis Pune University, 1982.

[11]. Rani, "Potential Women Entrepreneurs", A study, SEDME 13(3), National Institute of Micro, Small and Medium Enterprises, 1986, pp.13-32. 